\title{
Ghettos and Barrios: The Impact of Neighborhood Poverty and Race on Job Matching among Blacks and Latinos
}

\author{
JAMES R. ELLIOTT, Tulane University \\ MARIO SIMS, University of Wisconsin-Milwaukee
}

\begin{abstract}
Recent research suggests that racial and poverty concentrations in urban neighborhoods influence how minorities look for and find jobs. In this study, we use data from the Multi-City Survey of Urban Inequality to examine this hypothesis, focusing on the use and return to various modes of job matching among blacks and Latinos in different residential contexts. Results show that while Latinos are generally more likely than blacks to acquire jobs through personal contacts, this racial difference shrinks considerably in very poor, coethnic neighborhoods (i.e., ghettos and barrios). However, results also indicate that within these respective neighborhood contexts, Latinos are significantly more likely than blacks to use neighbors and eventual coworkers to acquire jobs; whereas blacks are more likely to use residential and organizational "outsiders." We speculate that this qualitative difference in the type of contacts used in barrios, as opposed to ghettos, affects the extent to which individual success with informal job matching contributes to the development of a collective resource that can be used by other job seekers in the neighborhood.
\end{abstract}

A long line of research in the sociology of labor markets established that individuals often acquire jobs through personal contacts rather than through formal channels (see Granovetter 1995 for a recent review). In other words, whom you know shapes your potential for employment and mobility, particularly toward the bottom of urban labor markets (Elliott 2000). Recently this argument has been invoked to understand the deleterious effects of disadvantaged neighborhoods on working-age, minority residents. Wilson $(1987,1996)$, for example, argued that poor, predominantly black neighborhoods tend to isolate workers from social contacts needed to succeed in today's urban labor markets, serving to reinforce pre-existing inequalities and contribute to the growth of an urban underclass.

The recent and widespread appeal of this argument masks the fact that we still know relatively little about the intersection of race, place, and job matching. In part, this deficiency stems from recent preoccupations with "spatial mismatches" of available jobs and inner-city job seekers-preoccupations that downplay the social mechanisms by which individuals actually learn about and acquire employment. When these social mechanisms are highlighted, evidence continues to underscore the importance of personal networks for finding work. For example, in a recent study of the Red Hook neighborhood of Brooklyn, Kasinitz and Rosenberg (1996) found that local blue-collar jobs are regularly filled via social networks that exclude nearby, minority residents (see also Aponte 1996; Cohn and Fossett 1996).

Survey research on personal networks and job matching could help to illuminate these dynamics and their generalizability across neighborhood contexts, but to date, this research

We would like to thank Joel Devine, Jim Wright, members of the Tulane Research Group, and anonymous reviewers for comments on earlier versions of this research. Direct correspondence to: James Elliott, Department of Sociology, 220 Newcomb Hall, Tulane University, New Orleans, LA 70118. E-mail: jre@tulane.edu.

SOCIAL PROBLEMS, Vol. 48, No. 3, pages 341-361. ISSN: 0037-7791; online ISSN: 1553-8533

(C) 2001 by Society for the Study of Social Problems, Inc. All rights reserved.

Send requests for permission to reprint to: Rights and Permissions, University of California Press,

Journals Division, 2000 Center St., Ste. 303, Berkeley, CA 94704-1223. 
has largely ignored the relevance of residential location for shaping both the quantity and quality of available job contacts. Thus, the influence of neighborhood context on labor market behaviors and outcomes remains poorly documented and ill understood. The purpose of the present study is to help fill this gap by examining the extent to which different neighborhood contexts-defined by racial and poverty concentration-affect the ways in which blacks and Latinos look for and acquire jobs in major U.S. cities. Our objective is to illuminate not only the social underpinnings of today's urban labor markets, but also how residential segregation shapes the life chances of America's two largest racial and ethnic minorities.

\section{Background}

In this section, we review recent research on racial differences in job networking and then consider how racially segregated and impoverished neighborhoods might influence these differences. After advancing formal hypotheses for investigation, we turn to the data and measures used to test them.

\section{Racial Variation in Job Networking}

While it is widely acknowledged that social networks play an important role in the job acquisition process, recent research suggests that this role is not evenly experienced across racial and ethnic lines. Specifically, quantitative research shows that Latinos are much more likely than other major racial and ethnic groups to acquire jobs through friends, relatives, and other personal contacts (Falcon 1995; Falcon and Melendez 1996; Green, Tigges, and Diaz 1999; Holzer 1987, 1988; Marx and Leicht 1992; Mier and Giloth 1985). By contrast, blacks are significantly more likely than other major racial and ethnic groups to rely on formal channels, such as answering classified ads, using public and private placement agencies, or simply walking in and applying for work (Elliott 2000; Falcon 1995; Falcon and Melendez 1996; Green, Tigges, and Diaz 1999; Holzer 1987, 1988; Marx and Leicht 1992). Explanations for this racial variation in job networking, while still evolving, typically emphasize a combination of supplyand demand-side factors.

The primary supply-side factor relates to the fact that a disproportionately large share of U.S. Latinos is foreign-born. This fact is relevant to racial differences in job networking in two key respects. First, the heavy reliance of immigrants on local and transnational networks means that a large number of Latinos in the U.S. have been "positively selected" on their successful utilization of network contacts, who typically assist newcomers with job placement, as well as with places to live and a sense of community (Aponte 1996; Hagan 1998; Massey, Alcaron, Durand, and Gonzalez 1987; Portes and Bach 1985). Second and relatedly, because large numbers of U.S. Latinos are foreign-born, many do not speak English well, may be in the country illegally, and may have a referent from their home countries that makes lowwage jobs appear more desirable than they appear to native-born workers. Both factors suggest that Latinos, as a group, are more likely to be embedded within active job networks and more likely to use these networks to take jobs quickly, avoiding more formal and protracted job searches.

On the demand-, or employer-, side of the labor market, explanations typically stress well-documented patterns of employer distaste for black workers (see Kirschenman and Neckerman 1991; Moss and Tilly 1996; Waldinger 1997; Wilson 1996). Whether this distaste results from outright racial prejudice or actual differences in productive or "soft" skills between blacks and other groups is relatively unimportant. The key point is that employers consistently rank blacks at the end of the racial/ethnic hiring queue and, as a result, are less likely to recruit and hire them through network channels. Consequently, as Holzer (1987, 1988) explains, blacks must rely more heavily on formal recruitment and hiring procedures 
than other racial and ethnic groups-a mode of job matching that, relative to networking, tends to emphasize credentials and experience, as opposed to skin color, in the screening and hiring processes.

Based on both lines of argument, we advance the following baseline hypothesis:

Hypothesis 1: Latinos are more likely than blacks to search for and acquire jobs through personal contacts.

The key question for the present study is whether the nature and magnitude of this racial difference varies with neighborhood context. We discuss this issue next.

\section{Place and Job Networking}

A fundamental assumption in recent studies and policy initiatives on urban inequality is that racially segregated and impoverished neighborhoods shape, as well as reflect, individual opportunities (Alba, Logan, and Bellair 1994; Briggs 1998; Brooks-Gunn, Duncan, and Aber 1997; Jargowsky 1997; Massey 1998; Massey, Gross, and Shibuya 1994; Rosenbaum and Popkin 1991). These so-called "neighborhood effects" are believed to be especially important for understanding minority opportunities because racial and ethnic minorities are more likely than whites to face restricted residential choices. Massey and Denton (1993) argue that these restrictions stem primarily from ongoing white prejudice in lending and housing markets, while Wilson $(1987,1996)$ contends that they reflect new economic circumstances that have emptied inner-city neighborhoods of their minority middle class. Either way, the effect has been disconcerting. According to Jargowsky's estimates (1997), the number of racially segregated, high-poverty neighborhoods in U.S. urban areas has more than doubled over the past two decades, as has the number of people living in them.

This proliferation of disadvantaged neighborhoods is important socially and politically not only because they house disproportionate shares of racial and ethnic minorities, but also because they exert independent and negative effects on a variety of social and psychological outcomes. These outcomes include cognitive development and educational attainment among children (Brooks-Gunn, Duncan, Klebanov, and Sealand 1993; Crane 1991; Entwisle, Alexander, and Olson 1994), sexual activity and fertility among adolescents (Billy and Moore 1992; Brewster, Billy, and Grady 1993; Hogan and Kitagawa 1985), and criminal victimization among all groups (Miethe and McDowall 1993; Smith and Jarjoura 1989). Research on labor market behaviors and outcomes remains less developed, but conventional wisdom points in similarly negative directions.

The most commonly cited negative effect of living in a racially segregated, high-poverty neighborhood is labor market detachment, or joblessness, which many observers attribute to a lack of proximate job opportunities and/or loss of "work ethic" among local residents. However, ethnographic research (Anderson 1990; Freidenberg 1995; Liebow 1967) and case studies of single urban areas (Kasinitz and Rosenberg 1996; Wilson 1996) suggest two other ways in which disadvantaged neighborhoods might negatively affect the labor market oppor tunities available to local residents. First, because disadvantaged neighborhoods typically have high rates of joblessness, they can reduce social interaction with current jobholders, who often serve as critical conduits of information about new job openings, many of which are never publicly listed. Second and relatedly, because disadvantaged neighborhoods discourage interaction with "mainstream" populations and institutions, they can also influence the type of job contacts residents have access to, thereby affecting the quality, as well as the quantity, of network assistance available to local job seekers (Elliott 1999).

In discussions of contemporary urban inequality, these "neighborhood effects" are typically assumed to exert themselves uniformly on all groups. However, further reflection suggests several reasons why these effects might vary by race and ethnicity, negatively affecting blacks more so than Latinos. The first reason is that most, if not all, of the research on neigh- 
borhood poverty and its negative effects on workers focuses on blacks. When attention turns to Latinos, discussion typically shifts from themes of extreme labor market isolation to the vibrancy of local job networks and the cultivation of local ethnic economies. This analytical disjuncture suggests that residence in disadvantaged neighborhoods may increase, rather than stabilize or suppress, observed racial differences in job networking, thereby exacerbating racial inequality and competition within contemporary urban labor markets. Two lines of reasoning support this possibility.

First, studies documenting employer discrimination against blacks often point to the importance of residential context for invoking negative racial stereotypes (see Kirschenman and Neckerman 1991; Moss and Tilly 1996; Waldinger 1997; Wilson 1996). The basic point is that while employers generally disfavor blacks, they strongly and specifically disfavor blacks from poor, inner-city neighborhoods-negative stereotypes are place-, as well as race-based. This fact not only makes it more difficult for black residents of disadvantaged neighborhoods to find jobs, it also suppresses their cultivation and use of effective employment networks. This suppression can occur in two mutually reinforcing ways. First, even if an employer "takes a chance" on a black, inner-city worker, he or she is still unlikely to use that employee's social networks to recruit more black, inner-city workers. Second and relatedly, if black workers sense this situation, and if their own hold on their jobs is precarious, then they may be less likely to risk their reputations by recommending friends and neighbors. The implication is that blacks in poor, black neighborhoods are less able to rely on job contacts to look for and acquire jobs than blacks in general, and when they do, they must rely more heavily on "outsiders" - that is, contacts who live beyond their immediate neighborhoods and work for different employers.

By contrast, there are reasons to suspect that among Latinos, disadvantaged neighborhoods actually increase the cultivation and use of localized job networks. The first reason is compositional. Because poor, Latino neighborhoods have high shares of foreign-born residents, and because foreign-born residents are more likely to pursue employment through personal contacts than native-born workers, job networking in these environments is likely to become intensely localized-we might call this the "density-amplification" effect. Another reason why job networking might be intensely localized in poor, Latino neighborhoods is because of return migration patterns and associated norms of reciprocity. The argument here is that many residents of poor, Latino neighborhoods likely cycle back and forth between their sending and receiving communities. So, one way that they can help ensure themselves of job opportunities in future return trips is by serving as job contacts during the time that they are living and working in the receiving community. This network activity not only helps others in similar situations, but presumably also increases one's odds of local, in-kind assistance on future return trips.

On the employer-side of the matching process, such dense and localized job networks have been shown to play an important role in the development of ethnic niches within urban economies, which researchers find to be much more prevalent among Latinos than nativeborn blacks (Light and Gold 2000; Logan, Alba, and McNulty 1994; Model 1993, 1997; Waldinger 1996). This point suggests that Latinos in disadvantaged neighborhoods are not only more likely to use friends and neighbors to look for and acquire jobs than blacks in disadvantaged neighborhoods, but that they are also more likely to use insider referrals, that is, contacts already working for prospective employers. Based on these complementary lines of reasoning, we advance two additional hypotheses for empirical investigation:

Hypothesis 2: Residence in poor, coethnic neighborhoods will increase differences between blacks and Latinos in the overall rate of informal job matching.

Hypothesis 3: Residence in poor, coethnic neighborhoods will lead blacks and Latinos to use different types of contacts to secure employment informally. 
In short, we suspect that neighborhood poverty and race influence both quantitative and qualitative differences in job networking among blacks and Latinos in major urban labor markets. We now turn to the data and measures used to assess this argument empirically.

\section{Data And Methodology}

Data for the present study come from the Multi-City Survey of Urban Inequality (MCSUI) conducted in Atlanta, Boston, and Los Angeles in 1992-1994. The sample is a multi-stage, stratified, area-probability design conducted in each of the three metro areas. Neighborhoods with large shares of ethnic minorities and low-income residents were over-sampled, and faceto-face interviews were conducted with randomly selected adults (age 21 and older) in sample households. The total sample contains information on 7,360 individuals, including 2,360 blacks and 1,752 Latinos (see Johnson, Oliver, and Bobo (1994) for more details on the MCSUI).

Within the diverse Latino sample, Mexicans comprise the largest subgroup (39 percent of respondents) and reside almost entirely in Los Angeles. Puerto Ricans and Dominicans comprise the next largest subgroups (20 percent and 13 percent of respondents respectively); each resides almost entirely in Boston. While data limitations preclude rigorous multivariate analysis for each Latino subgroup, we conduct side analyses, where possible, and report relevant findings in endnotes. However two patterns are worth noting at the outset. First, although often of African descent, Dominicans in our sample reside in block groups or neighborhoods, with the highest mean rate of Latino occupancy. Second, the average rate of neighborhood poverty for each Latino subgroup is higher than that for blacks in the sample. So, in short, Dominicans in our sample do not tend to reside in "black" neighborhoods, nor do any of the major Latino subgroups in our sample tend to reside in less impoverished neighborhoods than blacks.

Despite our inability to analyze specific Latino subgroups, several factors make the MCSUI ideal for examining issues of social isolation and job matching. First, each of the three metro areas under investigation experienced a recent increase in the number of residents living in highpoverty neighborhoods (Jargowsky 1997:222-233). So they are indicative of broader national trends. Second, local employment rates and median incomes in these areas have increased, both overall and among major racial and ethnic groups (Drennan, Tobier, and Lewis 1996), rendering issues of job matching and employment quality, as opposed to joblessness, particularly salient. Third, because the survey over-samples racial and ethnic minorities and residents of high-poverty neighborhoods, it provides sufficient cases for statistical analyses across multiple neighborhood contexts for both blacks and Latinos.

Information on neighborhood poverty and racial composition are attached at the level of block groups using data from the STF3 file of the 1990 U.S. Census of Population and Housing. The Census Bureau defines a block group as a collection of small areas, or blocks, bounded on all sides by visible features such as streets, railroad tracks, or invisible city and township boundaries. In size, a block group averages roughly four hundred households and about one thousand residents. We operationalize neighborhoods using block groups because they are smaller and more homogeneous than larger census tracts.

Because the MCSUI is a cross-sectional survey that asks questions about past job search activities, a key sampling issue is whether to include all respondents currently residing in a given neighborhood, or only respondents who report living there prior to their last job search. We choose the latter strategy because it highlights how neighborhoods affect job searching and hiring, instead of how success (failure) in the job market affects residential location. We also choose this strategy because scholarly and policy concerns typically focus on "isolation effects" among long-term residents of high-poverty neighborhoods. This selection criterion reduces the black sub-sample of recent job seekers ("stayers" + "movers") by 39 percent; it reduces the Latino sub-sample by 47 percent. 
While the restricted sample is important for maintaining the temporal/causal priority of neighborhood context, we recognize that selection works both ways. If persons with better job hunting strategies get better jobs that pay higher wages, which in turn allow them to relocate to better neighborhoods, then persons left behind are not a random sample. For this reason, we conduct our analyses for the full, unrestricted sample of movers and stayers as well, summarizing differences where notable. This information allows us to assess the nature of any biases that may result from our restricted sample of neighborhood stayers.

\section{Sample and Empirical Measures}

Within the above restrictions, we select job seekers between the ages of 21 and 64 who reported looking for work during the previous five years. The five-year restriction is a function of the survey instrument, which was designed to increase reliability by limiting the length of time under review. One might expect a more general sample of all job seekers to be older and, perhaps, less adventurous, since job tenure tends to increase with age and because job switching often involves risk. Like prior researchers, we assume these differences do not seriously bias our results (Granovetter 1974; Green, Tigges, and Diaz 1999; Falcon and Melendez 1996). Because poor households were over-sampled, we weight the data for descriptive statistics to reflect the racial and poverty distribution in each metro area, adjusting the weights to equal the original sample size.

Preliminary statistics on block group or neighborhood characteristics and labor market behavior for blacks and Latinos appear in Table 1. Although notable variation exists among the three sample metro areas, pooled statistics show that recent Latino job seekers generally live in more coethnically concentrated and impoverished neighborhoods than blacks-side analyses indicate that this is particularly true of Dominicans in Boston. Looking at specific neighborhood types reveals that 7 percent of recent black job seekers in the sample metro areas live in neighborhoods wherein at least 75 percent of the population is coethnic and 35 percent lives in poverty-we refer to this neighborhood type as "ghettos." By comparison, 10 percent of recent Latino job seekers in the sample metro areas live in neighborhoods wherein at least 75 percent of the population is coethnic and 35 percent lives in poverty-we refer to this neighborhood-type as "barrios."

Measures of job search and acquisition strategies come from two related sets of questions. First, recent job seekers were asked to identify all methods that they used in their last or current job search. If a respondent switched jobs during the previous five years, but reported no active search, he or she was not asked questions about search and acquisition processes and thus, is excluded from our analysis. This exclusion is unfortunate, but unavoidable. The upshot is that our estimates of informal assistance are likely to be conservative (i.e., biased downward), since it is generally assumed that "non-searchers" enter their new jobs with the help of personal contacts (Granovetter 1995).

If respondents report active searches and successful matches, they are asked more specific questions about how they acquired their jobs: "Did you find your (last/present) job through friends, relatives, other people, newspaper ads, or some other way?" For those who found their job through personal contacts, the characteristics of the contacts and the nature of the assistance were recorded. From this information, we examine whether respective job contacts were family or friends, neighbors, and/or insider referrers, thereby illuminating the type of network contacts used by job seekers in different neighborhood contexts. We also examine whether job contacts simply passed along information about jobs, as opposed to "vouching for" or hiring respective job seekers.

Preliminary results in Table 1 show that on average, most black and Latino job seekers use about four different strategies to look for work. For both groups, the most common of these strategies is using friends and newspaper advertisements, followed by using family 


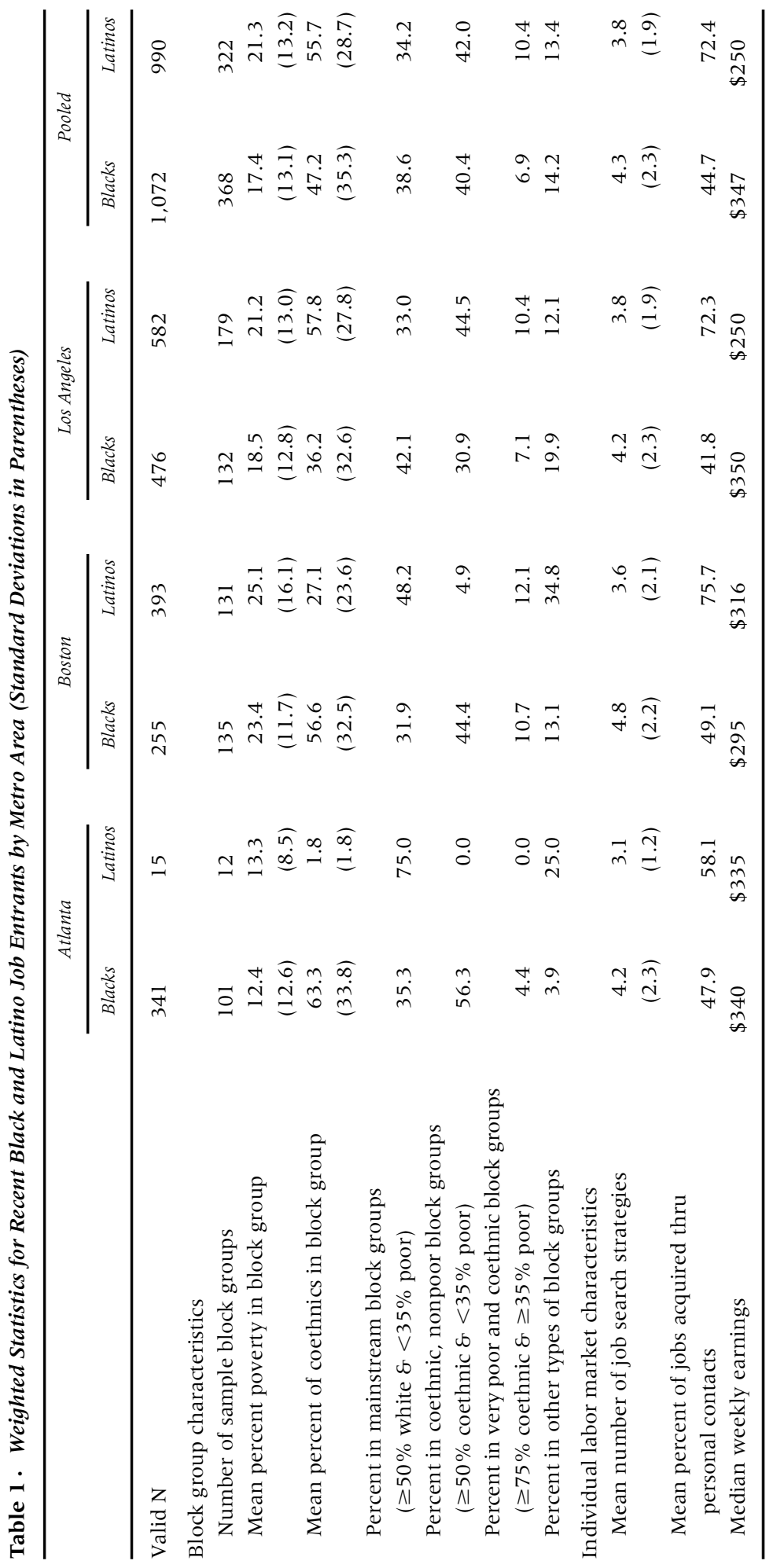


members and simply "walking in" off the street. We investigate these strategies and related patterns in the Results section below.

\section{Results}

We present the results of our empirical analysis in three sections. The first section reports mean statistics on job search and acquisition strategies by race and neighborhood type. For comparison purposes, we focus on three (non-exhaustive) types of neighborhoods: (1) majority white neighborhoods with poverty rates of less than 35 percent; (2) majority-coethnic neighborhoods with poverty rates of less than 35 percent; and (3) neighborhoods that are 75 percent coethnic with poverty rates of greater than or equal to 35 percent-i.e., "ghettos" and "barrios."

\section{Mean Differences in Job Search and Acquisition Rates by Race and Neighborhood Type}

Table 2 reports how blacks and Latinos look for jobs, stratified by neighborhood type. Focusing on the use of personal contacts, results reveal significant neighborhood variation among blacks, but not Latinos. Among blacks, the use of personal contacts to look for work increases from 70 percent in mostly white, non-poor neighborhoods to 80 percent in ghettos $(p<.01)$. Among Latino job seekers, the percentage that use personal contacts holds constant at roughly 86 percent, regardless of neighborhood type. Racial comparison within neighborhood types reveals no significant difference in the frequency of blacks in ghettos and Latinos in barrios using personal contacts to look for jobs-both groups are overwhelmingly likely to do so (80 and 87 percent respectively).

Results in the top row of Table 2 also indicate that the average job seeker is likely to use four distinct strategies to look for work, regardless of his or her race or neighborhood type. Thus, a key question becomes, which types of strategies are most likely to lead to employment and whether the answer varies by race and neighborhood context. Table 3 addresses this issue, providing summary statistics on the primary method respondents used to acquire their last/current jobs. As with search strategies, results again reveal significant neighborhood variation among blacks, but not Latinos. For blacks, the lowest rate of informal job matching occurs in mostly white, non-poor neighborhoods (39 percent) and increases in black, nonpoor neighborhoods ( 52 percent) and ghettos (46 percent). Further comparisons show that in each neighborhood type, Latinos are significantly more likely to acquire jobs through personal contacts than blacks-a finding consistent with general racial differences documented in prior research (Falcon 1995; Green, Tigges, and Diaz 1999). The largest of these racial differences occurs in ghettos and barrios: 46 percent of black jobholders in ghettos report obtaining their last/current job through personal contacts compared with 75 percent Latino jobholders in bar rios (a difference which is statistically significant at the .001-level.) ${ }^{1}$

While this large ghetto-barrio disparity lends prima facie support to Hypothesis 2, perhaps the most intriguing part of this finding is that it occurs despite the fact that there is no significant disparity in the likelihood of using personal contacts to look for work (see Table 2). This pattern suggests that blacks in ghettos do not lack job contacts per se, as recent writings on the underclass sometimes suggest. Instead, ghetto residents lack job contacts that lead to employment, either because the contacts fail to generate offers or because the offers they do generate are less attractive than those received through formal channels. Because we have no direct data on the sequencing of job search behavior or range of offers that includes the most

1. In barrios, the highest rate of informal job acquisition is among Mexicans in Los Angeles at 83 percent. The lowest rate is among Dominicans in Boston at 70 percent, which is still significantly higher than the black ghetto rate of 46 percent $(\mathrm{p}<.02$ based on chi-square test). 


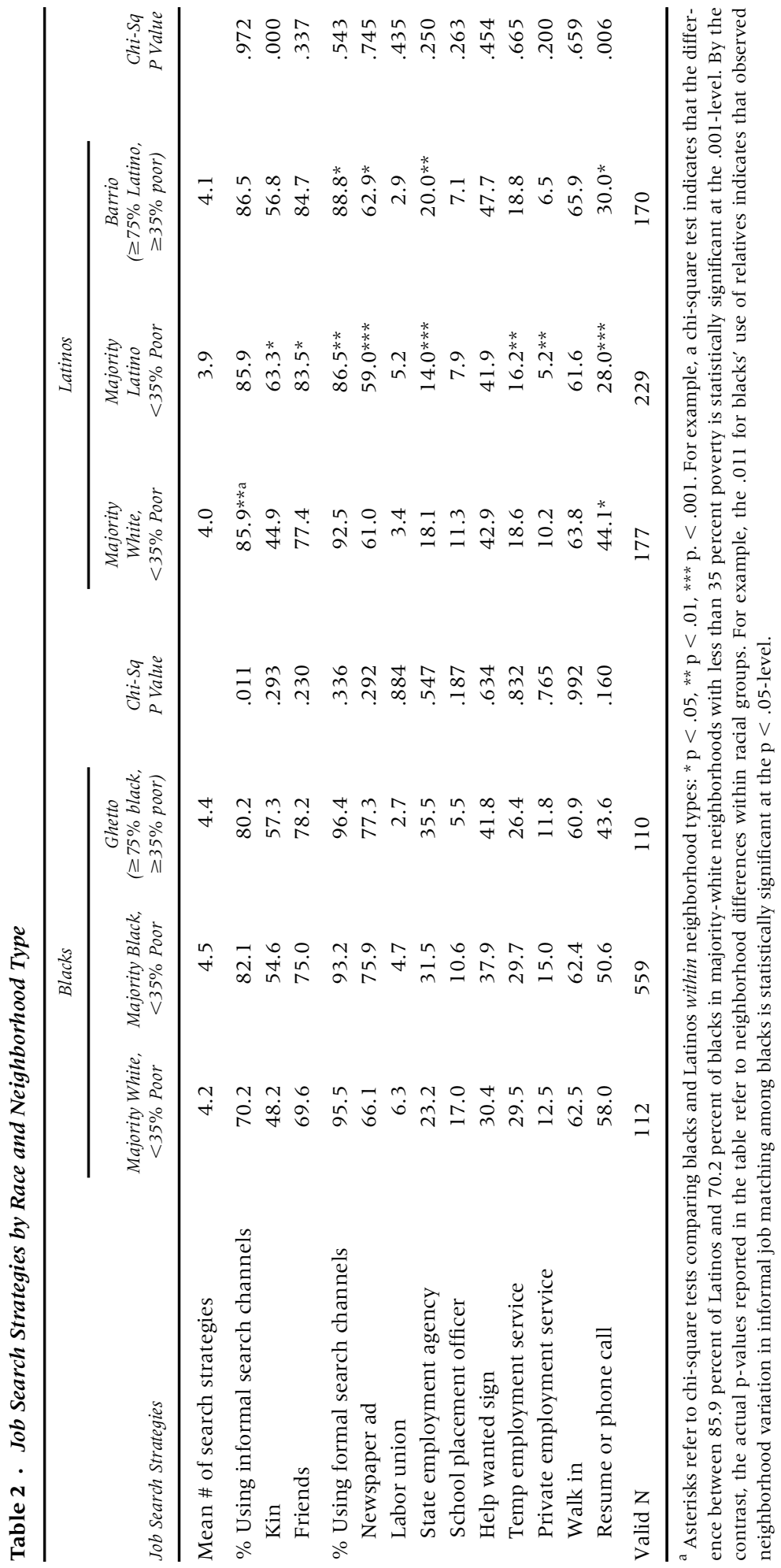




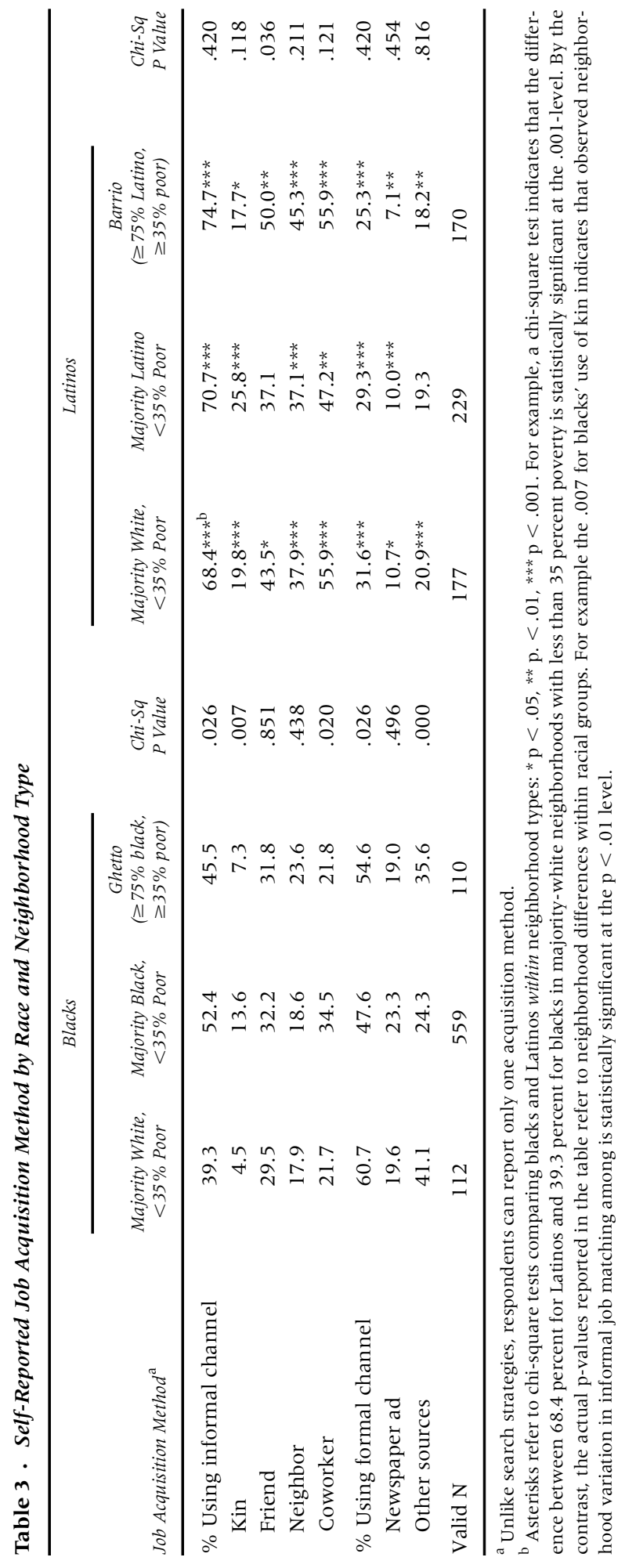


recent job, it would be premature to conclude that the contacts used by barrio residents are more "effective" than those used by ghetto residents. It could simply be that barrio residents are more likely to take the first job offered, whereas ghetto residents are more likely to await better offers obtained through formal channels. We wrestle with this issue in our analysis of weekly earnings below.

For now, another key question regarding informal job matching is how job contacts help respective job seekers acquire employment-a subject that has attracted little empirical attention in prior quantitative studies. To investigate this issue, we restrict our analysis to jobholders who report using personal contacts to acquire their last/current jobs. Findings in Table 4 show that among blacks, the most common form of network assistance, regardless of neighborhood context, is having someone pass along information about a job opening. This type of assistance is especially prevalent in ghettos, accounting for 62 percent of network hires. By contrast, Latinos are much more likely to have job contacts "vouch" for them, that is, to talk to prospective employers on their behalf. This type of assistance is 2.6 times more likely among Latinos in barrios than blacks in ghettos $(47$ percent compared with 18 percent; $p<.001){ }^{2}$

To assess the sensitivity of these results to our sampling strategy, we compared them with results from the full sample of network hires, which includes neighborhood "movers" plus neighborhood "stayers." Findings reveal little difference between the two sampling strategies with one exception. Our focus on neighborhood "stayers" tends to overstate the percentage of ghetto and barrio residents who are "vouched for" by their job contacts by a factor of roughly 1.5. The implication is that longer-term residents of poor, coethnic neighborhoods are more likely than newcomers to be "vouched for" when using personal contacts to acquire jobs, regardless of their race/ethnicity. However, the relative difference between blacks and Latinos in these settings remains largely unchanged from that reported in Table 4.

\section{Logistic Regression Analyses of Job Acquisition}

To determine whether the above differences are statistically significant after controlling for background characteristics such as immigrant status, gender, human capital, and city of residence, we use logistic regression techniques to predict respective modes of job acquisition. Rather than stratifying analyses by neighborhood type, we use categorical measures for all levels of neighborhood coethnicity and poverty to help disentangle the relative effects of each ecological dimension on individual job matching behavior. This approach also permits us to include all respondents in our sample, rather than just those residing in the three neighborhood types presented in Tables 2-4. Results of these logistic regression analyses appear in Table 5. To make sense of the interaction terms, we recover respective odds ratios in Table 6 for blacks and Latinos residing in different neighborhood contexts. These odds ratios are net of the other observed variables in Table 5 and are computed by summing appropriate coefficients and taking the inverse $\log$ of the total.

Results in Column 1 of Table 5 confirm that, in general, Latinos are significantly more likely than blacks to acquire jobs informally, net of others factors, 1.8(exp .561) times more likely, to be exact. However, results also show that after controlling for background factors, this racial difference shrinks considerably in very poor, very coethnic neighborhoods (i.e., in block groups that are at least 75 percent coethnic and 35 percent poor) ${ }^{3}$ In these "problem"

2. In barrios, the likelihood of having a job contact vouch for the job seeker, given an informal match, is highest among Puerto Ricans at 75 percent, as compared with 18 percent among black ghetto residents. So, while the experiences of poor, inner city Puerto Ricans might be similar to those of poor, inner-city blacks in some respects (e.g., educational attainment and unemployment), these similarities do not imply similarities in the types of informal job assistance received.

3. Re-analysis with dummy variables for the four major Latino subgroups in our sample-Mexicans, Puerto Ricans, Dominicans, and "other Latinos"-reveals the same basic pattern for all subgroups. Net of other factors in the model, Puerto Ricans exhibit the highest odds of informal job matching (2.0 times those of blacks, all else equal). The smallest differential occurs among Mexicans, whose odds are 1.7 times those of blacks, all else equal. These findings suggest that we lose less detail than we might suspect when we compare job matching between blacks and "Latinos" as a whole. 


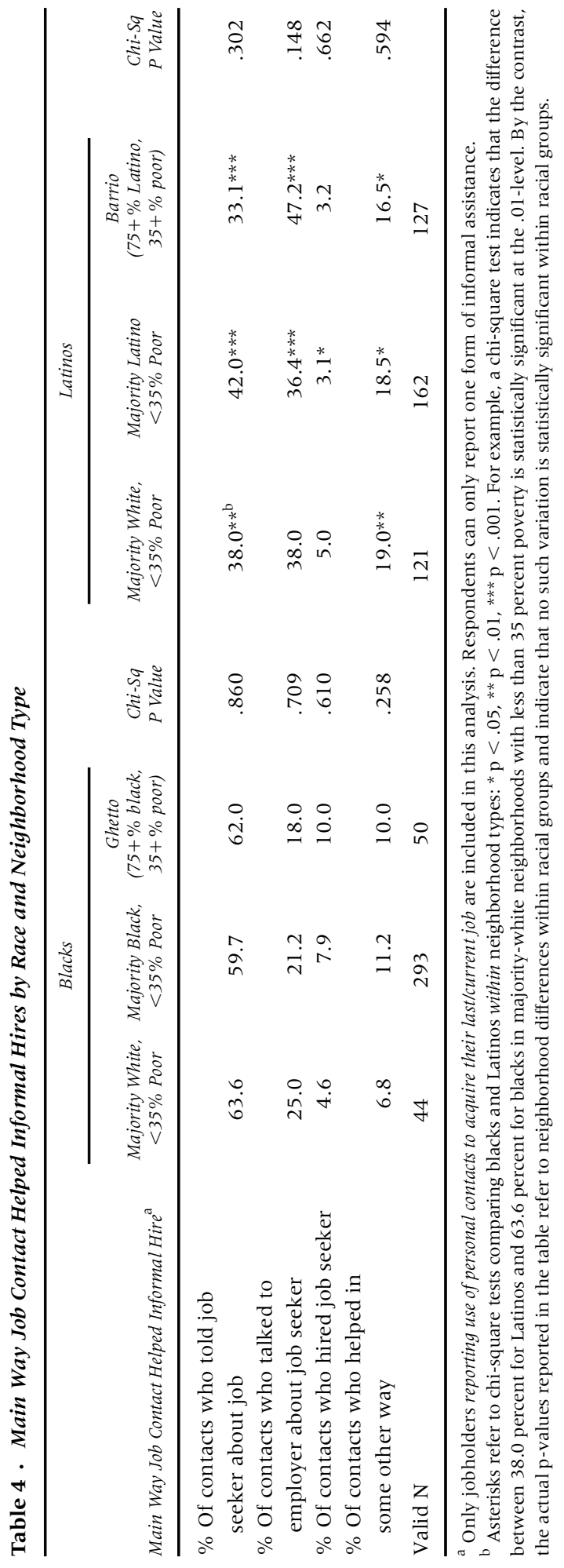


Table 5 • Log-Odds Coefficients for Respective Modes of Job Acquisition

\begin{tabular}{|c|c|c|c|c|}
\hline \multirow[b]{2}{*}{ Independent Variables } & \multirow{2}{*}{$\begin{array}{c}\text { Informal Job } \\
\text { Acquisition } \\
(1=\text { yes; } 0=n o)\end{array}$} & \multicolumn{3}{|c|}{ Informal Hires Only } \\
\hline & & $\begin{array}{l}\text { Kin or Friend } \\
(1=\text { yes } ; 0=n o)\end{array}$ & $\begin{array}{c}\text { Neighbor } \\
(1=\text { yes } ; 0=n o)\end{array}$ & $\begin{array}{l}\text { Inside Referrer } \\
(1=\text { yes } ; 0=\text { no })\end{array}$ \\
\hline Black (ref.) & - & - & - & - \\
\hline Latino & $.561 *$ & .016 & -.203 & .439 \\
\hline \multicolumn{5}{|l|}{ Block group characteristics } \\
\hline$<20 \%$ poor (ref.) & - & - & - & - \\
\hline $20-34 \%$ poor & .017 & $.939 *$ & .033 & .160 \\
\hline $35+\%$ poor & -.048 & -.224 & .091 & -.329 \\
\hline $0-24 \%$ coethnic (ref.) & - & - & - & - \\
\hline $25-49 \%$ coethnic & .379 & -.350 & -.310 & .153 \\
\hline $50-74 \%$ coethnic & .344 & -.092 & -.184 & -.199 \\
\hline $75+\%$ coethnic & $.394 *$ & -.432 & -.425 & -.324 \\
\hline \multicolumn{5}{|l|}{ Interaction terms } \\
\hline Latino $\times 20-34 \%$ poor & .489 & -1.528 & -.474 & $-1.039 * *$ \\
\hline Latino $\times 35+\%$ poor & .451 & -.353 & -.431 & -.268 \\
\hline Latino $\times 25-49 \%$ coethnic & -.466 & .670 & .655 & .040 \\
\hline Latino $\times 50-75 \%$ coethnic & $-.715^{*}$ & .543 & .802 & .575 \\
\hline Latino $\times 75+\%$ coethnic & $-.806^{*}$ & .976 & $1.052 * *$ & .550 \\
\hline \multicolumn{5}{|l|}{ Controls } \\
\hline No. of search strategies & -.009 & -.017 & .021 & -.047 \\
\hline Female & $-.394 * * *$ & -.340 & .246 & -.057 \\
\hline Age (yrs.) & -.005 & -.017 & .011 & .002 \\
\hline Work experience (yrs.) & -.007 & .015 & $-.021^{*}$ & .004 \\
\hline Less than high school (ref.) & - & - & - & - \\
\hline High school degree & -.154 & .024 & $-.294^{*}$ & .049 \\
\hline Community college degree & $-.418^{*}$ & -.153 & -.154 & -.091 \\
\hline Four-year college degree & $-.605^{* *}$ & $-.999 * *$ & $-.754^{* *}$ & -.222 \\
\hline Foreign born & .205 & -.130 & .130 & -.272 \\
\hline Poor English ability & $.709 * * *$ & .579 & $.348 *$ & .302 \\
\hline Years at current address & -.003 & -.023 & -.010 & .006 \\
\hline Atlanta & -.082 & .462 & .042 & -.123 \\
\hline Boston & -.121 & .406 & $.482 * *$ & $.369 *$ \\
\hline Los Angeles (ref.) & - & - & - & - \\
\hline Constant & .525 & $2.821^{* *}$ & -.398 & $.947 *$ \\
\hline $\mathrm{N}$ & 2,048 & 1,228 & 1,228 & 1,228 \\
\hline
\end{tabular}

$* \mathrm{p}<.05 \quad * * \mathrm{p}<.01 \quad * * * \mathrm{p}<.001$

environments-a.k.a. ghettos and barrios - the odds of Latino jobholders acquiring jobs informally are only 1.2 times greater than those of black jobholders-a statistically insignificant difference. This convergence occurs because the extreme "blackness" of ghettos is positively correlated with blacks' odds of informal job matching, whereas the extreme "Latin-ness" of barrios is negatively correlated with Latinos' odds of informal job matching. The corollary finding is that, net of other factors, the greatest black-Latino difference in informal job matching occurs in neighborhoods where respective members are in the minority, not where they are ethnically concentrated.

Remaining columns and panels in Tables 5 and 6 report the likelihood of using specific types of job contacts to acquire jobs, given an informal match. The first type of contact 
Table 6 - Odds Ratios Recovered from Table 5 and Depicting the Interaction Effects of Neighborhood Poverty and Coethnicity on Informal Job Matching, by Race

\begin{tabular}{|c|c|c|c|c|c|c|}
\hline \multirow{2}{*}{$\begin{array}{l}\% \text { Coethnic in } \\
\text { Neighborhood }\end{array}$} & \multicolumn{3}{|c|}{$\begin{array}{l}\text { Black } \\
\text { Neighborhood Poverty Level }\end{array}$} & \multicolumn{3}{|c|}{$\begin{array}{l}\text { Latino } \\
\text { Neighborhood Poverty Level }\end{array}$} \\
\hline & $<20 \%$ & $20-34 \%$ & $35+\%$ & $<20 \%$ & $20-34 \%$ & $35+\%$ \\
\hline \multicolumn{7}{|c|}{ Odds of Informal Job Match (from Table 5, Column 1) } \\
\hline$\leq 25$ & {$[$ ref. $=1]$} & 1.02 & 0.95 & 1.75 & 1.78 & 2.62 \\
\hline $25-4$ & 1.46 & 1.46 & 1.39 & 1.61 & 2.66 & 2.40 \\
\hline $50-74$ & 1.41 & 1.44 & 1.35 & 1.21 & 2.01 & 2.02 \\
\hline $75-100$ & 1.48 & 1.51 & 1.41 & 1.16 & 1.93 & 1.74 \\
\hline \multicolumn{7}{|c|}{ Odds of Using Kin or Friend, Given Informal Match (from Table 5, Column 2) } \\
\hline$\leq 25$ & {$[$ ref. $=1]$} & 2.56 & 0.80 & 1.02 & 1.42 & 0.57 \\
\hline $25-49$ & 0.70 & 1.80 & 0.56 & 0.72 & 0.78 & 0.79 \\
\hline $50-74$ & 0.91 & 2.33 & 0.32 & 0.93 & 0.89 & 0.90 \\
\hline $75-100$ & 0.65 & 1.66 & 0.52 & 0.66 & 0.97 & 0.98 \\
\hline \multicolumn{7}{|c|}{ Odds of Using Neighbor, Given Informal Match (from Table 5, Column 3) } \\
\hline$\leq 25$ & {$[$ ref. $=1]$} & 1.03 & 1.10 & 0.82 & 0.53 & 0.58 \\
\hline $25-49$ & 0.73 & 0.76 & 0.80 & 1.15 & 0.74 & 0.82 \\
\hline $50-74$ & 0.83 & 0.86 & 0.91 & 1.52 & 0.97 & 1.08 \\
\hline $75-100$ & 0.65 & 0.68 & 0.72 & 1.53 & 0.98 & 1.09 \\
\hline \multicolumn{7}{|c|}{ Odds of Using Insider Referral, Given Informal Match (from Table 5, Column 4) } \\
\hline$\leq 25$ & {$[$ ref. $=1]$} & 1.17 & 0.72 & 1.55 & 0.64 & 0.85 \\
\hline $25-49$ & 1.16 & 1.37 & 0.84 & 1.88 & 0.78 & 1.04 \\
\hline $50-74$ & 0.82 & 0.96 & 0.59 & 2.26 & 0.94 & 1.24 \\
\hline 75-100 & 0.72 & 0.85 & 0.52 & 1.94 & 0.81 & 1.07 \\
\hline
\end{tabular}

Note:

These odds ratios have been recovered from Table 5 by summing the relevant coefficients and then taking the inverse $\log$ of the total.

examined is friends and family, or "strong" ties. Excluding formal matches, results reveal no significant overall difference between blacks and Latinos in general. However, results also indicate that Latinos in barrios are nearly twice as likely as blacks in ghettos to use strong ties to acquire jobs - an odds ratio of 0.98 compared with 0.52 , net of background factors. ${ }^{4}$ This racial difference emerges as the result of countervailing patterns among blacks and Latinos in highpoverty neighborhoods: among blacks in high poverty neighborhoods, racial concentration is negatively correlated with the use of strong ties; among Latinos in high poverty neighborhoods, it is positively correlated.

Significant racial and neighborhood differences also appear in the use of neighbors and insider referrers. Starting with neighbors, results show that their use increases with neighborhood coethnicity among Latinos, but decreases among blacks. As a result, Latinos in barrios are about $1.5(1.09 / .72)$ times more likely than blacks in ghettos to use neighbors when finding jobs informally. The flipside is that blacks in ghettos are 1.5 times more likely than Latinos in barrios to use contacts outside their neighborhoods, given an informal match. To determine if this finding is more a function of neighborhood joblessness than poverty and coethnicity, we re-ran the models in Table 5 with a control variable for the percentage of residents

4. Re-analysis indicates that the Latino subgroup most likely to acquire jobs through friends and family in the barrio, net of other factors, is Puerto Ricans (3.2 times more likely than blacks in ghettos), followed by Mexicans (1.9 times more likely than blacks in ghettos), and finally Dominicans (0.6 times more likely than blacks in ghettos). 
sixteen years and older who were unemployed or not in the labor force. Results of this supplemental analysis (not shown) reveal no significant changes in the relationships presented in Table 5.5

In examining the use of insider referrers-contacts already working for prospective employers-we find the same basic pattern. Among Latinos, the use of insiders increases with neighborhood coethnicity, but among blacks, it decreases. As a result, Latinos in barrios are $2.1(1.07 / 0.52)$ times more likely than blacks in ghettos to acquire jobs through insider referrers, given an informal match and net of other factors. ${ }^{6}$ Together, these findings begin to produce a broad portrait of racial and neighborhood differences in informal job matching-one that highlights qualitative differences in the types of contacts used to acquire jobs, rather than quantitative differences in the overall likelihood of such use. Specifically, results indicate that when barrio residents look for and acquire jobs, they tend to use contacts that are close to themselves socially (strong ties), spatially (neighbors), and organizationally (insider referrers); whereas, when ghetto residents look for and acquire jobs, they tend to rely on contacts that are further from themselves socially (acquaintances) and spatially (non-neighbors).

One explanation for this qualitative difference lies with heightened employer distaste for blacks in ghettos compared with Latinos in barrios. Another explanation lies with potential earnings variation in the use of different types of job contacts among blacks and Latinosvariation that could encourage members of each racial group to pursue different types of job contacts. To explore the latter possibility, we use Ordinary Least Squares regression to examine the effects of respective modes of job matching on weekly earnings. Before we discuss the logic and results of this analysis, however, it is worth briefly reviewing the other background variables that significantly influence the odds of informal job matching among blacks and Latinos.

Column 1 of Table 5 shows that the strongest background factor is poor English ability, which doubles the odds (exp .709 or 2.03) of informal job matching, all else equal. The fact that this variable, and not foreign-born status, is statistically significant suggests that English ability plays the key mediating role in understanding Latino immigrants' well-documented propensity to acquire jobs informally (Hagan 1998; Massey, Alcaron, Durand, and Gonzalez 1987; Portes and Bach 1985). To determine if this mediating effect is truly a function of language skills and not a proxy for time in the U.S., we re-estimated the model in Column 1 of Table 5, adding a measure for the number of years elapsed since an immigrant first came to live in the U.S. Results (not shown) confirm that English ability is the more important of these two variables in explaining immigrants' propensity to acquire jobs informally.

Like English ability, educational credentials are also inversely correlated with informal job matching-the higher one's degree, the lower one's odds of acquiring a job informally. Finally, results also indicate that women are only two-thirds as likely as men to acquire jobs informally, all else equal. This finding is consistent with Hanson and Pratt's (1995) study of gender and informal job matching in Worcester, Massachusetts and likely reflects the intersection of two social facts: the homophily of social relations and men's greater labor force attachment. In other words, because individuals tend to develop social ties within, rather than between,

5. As one might expect, neighborhood joblessness rates are higher in ghettos than barrios. In our sample, the respective percentages are 62.2 and 53.9. The only supplemental model in which this variable reached statistical significance at the .05 -level was in the prediction of using a neighborhood contact, given an informal match. Contrary to expectation, results indicate that neighborhood joblessness is positively correlated with the use of neighborhood contacts among Latinos; among blacks, there is no significant effect. Because of our concerns with colinearity, we re-ran the models with and without indicators for neighborhood poverty and coethnicity. We did this both for the pooled sample and for blacks and Latinos, separately. The same basic findings prevailed. These supplemental results reinforce the image of Latino barrios as sites of highly insular and localized job networks, even in the face of general labor market disadvantage.

6. Re-analysis suggests that all Latino subgroups in barrios are about equally likely to acquire jobs informally through neighbors but that there is significant variation in the use of insider referrers: Puerto Ricans in barrios are about three times more likely than Mexicans and Dominicans in barrios to acquire jobs informally with the help of insider referrers (six times more likely than blacks in ghettos). 
groups and because men tend to spend more time in the labor market than women over their lifetimes, men are more likely to know and use personal contacts to acquire jobs than women. Patterns may differ in the informal economy.

\section{Regression Analyses of Weekly Earnings}

In our final set of analyses, we use Ordinary Least Squares regression to examine the effects of respective modes of job matching on weekly earnings, logged to approximate a nor mal distribution. ${ }^{7}$ If results show that blacks who acquire jobs through strong ties, neighbors, and/or insider referrers earn significantly less than blacks who use other modes of job matching, it would suggest that the relatively infrequent use of such contacts by blacks in ghettos reflects proactive pursuit of better job opportunities. If, on the other hand, such contacts exert no earnings penalty and/or lead to higher paying jobs, evidence would suggest that their infrequent use in ghettos stems from their failure to generate job offers. For comparison pur poses, we estimate the earnings model four times: once for the pooled sample, and once for respondents at each level of neighborhood poverty ( $<20$ percent; $20-34$ percent; $\geq 35$ percent). In all four models, neighborhood coethnicity is controlled as a set of dummy variables.

Results appear in Table 7, with Column 1 reporting coefficients for the pooled sample. Several findings emerge from this analysis. First, in comparison with other modes of job matching, neighborhood contacts exert a negative effect on weekly earnings- the only significant effect among the respective job matching variables. Second, none of the neighborhood coethnicity variables are significantly correlated with individual earnings. This is true in all models and suggests that to the extent to which racial segregation influences earnings inequality among blacks and Latinos, it does so indirectly through its contribution to neighborhood poverty or some other mediating variable. All other variables in the model behave as expected: earnings are higher for men and individuals with more education and work experience; whereas, earnings are lower for women, individuals with poor English ability, and residents of impoverished neighborhoods. City of residence has no significant effect.

Results for sub-samples stratified by neighborhood poverty (Columns 2-4) reveal that the negative effect of using a neighborhood contact occurs only in high poverty neighborhoods and really only for blacks. Specific calculations show that among blacks in high poverty neighborhoods, jobs acquired through neighbors pay 25 percent less than jobs acquired through other modes of job search, net of other factors ( $\$ 174 /$ week compared with $\$ 230 /$ week). By contrast, the wage penalty associated with neighborhood contacts among Latinos in barrios is less than 10 percent ( $\$ 190 /$ week compared with $\$ 210 /$ week) and is statistically insignificant, all else equal. No other job matching variables are statistically significant in the model for high-poverty neighborhoods.

These findings suggest that there is a stronger financial incentive for ghetto residents to expand their job search networks beyond their immediate neighborhoods than there is for barrio residents. To the extent that there is role overlap between neighbors, strong ties, and potential insider referrers, this "neighborhood incentive" may also help to explain why ghetto residents are less likely to use these other types of contacts to acquire jobs, relative to barrio residents. We elaborate on these possibilities below.

\section{Discussion and Conclusion}

In this study, we sought to illuminate the extent to which neighborhood context influences the labor market strategies and outcomes of urban blacks and Latinos. Two central conclusions

7. In all our regression analyses we use STATA's survey regression function to correct for the correlation of individuallevel attributes within block groups, thus lending a conservative bias to our tests of statistical significance. Equations are calculated using unweighted data per discussion by Winship and Radbill (1994). 
Table 7 - Ordinary Least Squares Regression Analysis of Weekly Earnings (Logged)

\begin{tabular}{|c|c|c|c|c|}
\hline \multirow[b]{2}{*}{ Independent Variables } & \multirow[b]{2}{*}{ Pooled Sample } & \multicolumn{3}{|c|}{ Block Group Poverty Rate } \\
\hline & & $<20 \%$ & $20-34 \%$ & $35+\%$ \\
\hline Black (ref.) & - & - & - & - \\
\hline Latino & $-.092 *$ & .002 & $-.166^{*}$ & -.091 \\
\hline \multicolumn{5}{|l|}{ Block group characteristics } \\
\hline$<20 \%$ poor (ref.) & - & & & \\
\hline $20-34 \%$ poor & $-.107 * *$ & & & \\
\hline $35+\%$ poor & $-.134^{* * *}$ & & & \\
\hline$<25 \%$ coethnic (ref.) & - & - & - & - \\
\hline $25-49 \%$ coethnic & -.026 & -.062 & .023 & -.019 \\
\hline $50-74 \%$ coethnic & -.022 & -.050 & -.037 & -.019 \\
\hline $75+\%$ coethnic & -.064 & -.053 & -.069 & -.060 \\
\hline \multicolumn{5}{|l|}{ Job acquisition method } \\
\hline Kin or Friend $(0: 1)$ & .071 & .046 & .098 & .097 \\
\hline Neighbor $(0: 1)$ & $-.177^{* *}$ & -.183 & -.071 & $-.277^{* *}$ \\
\hline Inside referrer $(0: 1)$ & -.086 & -.037 & $-.168^{*}$ & -.034 \\
\hline Other type of personal contact $(0: 1)$ & .050 & -.056 & .485 & -.104 \\
\hline \multicolumn{5}{|l|}{ Interaction terms } \\
\hline Latino $\times$ kin/friend & -.053 & -.102 & -.063 & -.053 \\
\hline Latino $\times$ neighbor & .054 & .068 & -.110 & .175 \\
\hline Latino $\times$ inside referrer & .120 & -.056 & $.308^{* *}$ & .080 \\
\hline Latino $\times$ other personal contact & -.020 & -.282 & -.273 & .198 \\
\hline \multicolumn{5}{|l|}{ Controls } \\
\hline Female & $-.148^{* * *}$ & $-.242^{* * *}$ & $-.174^{* *}$ & -.052 \\
\hline Less than high school (ref.) & - & - & - & - \\
\hline High school degree & $.228 * * *$ & $.341 * * *$ & .165 & $.188 * * *$ \\
\hline Community college degree & $.278 * * *$ & $.347 * * *$ & $.163 *$ & $.337 * * *$ \\
\hline Four-year college degree & $.676 * * *$ & $.809 * * *$ & $.521 * * *$ & $.707 * * *$ \\
\hline Work experience (yrs.) & $.029 * * *$ & $.035 * * *$ & $.031 * * *$ & $.021 * * *$ \\
\hline Work experience (yrs.) squared & $-.001^{* * *}$ & $-.001^{* *}$ & $-.001 *$ & $-.001^{*}$ \\
\hline Poor English ability & $-.112 * *$ & -.040 & $-.180^{* *}$ & -.084 \\
\hline Atlanta & -.013 & .007 & -.079 & .474 \\
\hline Boston & .018 & -.026 & -.054 & .064 \\
\hline Los Angeles (ref.) & - & - & - & 一 \\
\hline Constant & $5.443 * * *$ & $5.375 * * *$ & $5.405 * * *$ & $5.297 * * *$ \\
\hline $\mathrm{N}$ & 2,056 & 687 & 647 & 722 \\
\hline
\end{tabular}

emerge from our efforts. First, "neighborhood effects" associated with extreme racial and poverty concentration appear to mute, rather than amplify, well-documented differences between blacks and Latinos in the likelihood of using personal contacts to look for and acquire employment. This finding is important because it challenges the orthodoxy that ghetto residents are uniquely isolated with respect to job contacts, especially in comparison with Latinos in barrios. Our second conclusion is that despite this similarity, job seekers in ghettos and barrios use very different contacts to acquire employment-racial differences in job networking are more qualitative than quantitative in racially segregated, high-poverty environments. Specifically, barrio residents are much more likely than ghetto residents to use friends or family, neighbors, and insider referrers 
to acquire jobs, and these contacts often "sponsor," or "vouch for," respective job seekers. By contrast, ghetto residents are much more likely to rely on non-neighbors and organizational outsiders to find jobs, and these contacts often merely pass along information about available positions.

The overarching picture then, is one in which barrio residents develop highly localized and densely connected employment networks that connect residents to jobs; whereas in ghettos, residents are more likely to cultivate and rely on ego-centric contacts "on the outside" beyond the local neighborhood and outside immediate ethnic niches. While our research cannot fully explain this qualitative difference in job networking between ghettos and barrios, it does offer clues. One such clue is financial. Specifically, findings show that ghetto residents who acquire jobs through neighbors tend to earn significantly less than those who acquire jobs through other channels, all else equal; whereas, the same is not true for barrio residents. This pattern suggests that one reason ghetto residents use "outsiders" more often than barrio residents is because there is material incentive to do so. Of course this line of explanation leads us to ask why a "neighborhood disincentive" exists in ghettos, but not barrios, in the first place.

In considering this question, contextual differences in human capital seem an unlikely culprit, since average educational attainment and English language skills tend to be lower in barrios than ghettos. This fact brings us back to the issue of employers' distaste for black, inner-city workers (Holzer 1996; Kirschenman and Neckerman 1991; and Moss and Tilly 1996; Waldinger 1997; Wilson 1996). This distaste, whether rooted in real or imagined differences in productivity, has the potential to restrict the formation of densely connected and highly localized employment networks in two important ways. First, by placing inner-city blacks at the end of the racial hiring queue, employer prejudice channels ghetto residents into low-paying jobs relative to their educational attainment and English-language skills, which, in turn, probably encourages them to look beyond neighbors and potential coworkers in hopes of finding better-paying jobs. The second way employer distaste might dissuade localized job networking is by discouraging insider referrals from ghetto residents who do acquire better paying jobs. Employers might make individual exceptions, but prior research suggests that they are very unlikely to cultivate employee networks that attract black, inner-city workers in large numbers. Sensing this, black, inner-city workers who have "made it" may also be unlikely to risk their workplace reputation by referring friends and neighbors.

Contributing to these qualitative differences in job networking could also be the fact that disproportionately large shares of Latinos in barrios are immigrants, many of whom do not speak English well and may be in the country illegally. These attributes, coupled with wage referents that make low-paying jobs in the U.S. look relatively attractive, could encourage barrio residents to accept whatever jobs they can get quickly, often through local, insider referrers. Ghetto residents, by contrast and by virtue of being U.S. citizens, have more ready access to welfare and unemployment benefits, allowing them to be more selective in their job searches: Rather than accept low-paying jobs through neighborhood contacts, ghetto residents may choose to prolong their job searches and, if no acceptable offers are forthcoming, even drop out of the labor market altogether. Related to these structural issues is the fact that ghetto residents, again by virtue of being native-born, are likely to know their rights and demand them more readily than barrio residents, making them less desirable workers for lowwage employers.

Our speculation on these issues points to one of the limitations of the present study, namely, that we have limited information on the "black box" that encompasses searches and hires. Our data, like most survey data on job matching, tells us only about the last/current job acquired by individuals and not about the range of offers from which it was selected. So it could be that ghetto residents use the same types of contacts to look for and acquire offers as barrio residents, but then, for whatever reason (e.g., low pay, unpleasant working conditions, lack of health insurance), choose not to accept these offers. Along those lines, we lack data on how individuals sequence their job searches. Do job seekers, as some observers assume (e.g., 
Montgomery 1992), begin their searches with methods they believe will yield the highest returns and proceed to other methods only when these initial "maximizing" strategies fail? Or, do job seekers begin with methods that are the most convenient, that is, "cost" the least?

Although we have been unable to address these issues directly in the present study, we have uncovered additional clues that can help inform future research on this subject. First, regression analyses show that the number of strategies used to look for work is insignificantly correlated with informal job acquisition. This "non-finding" suggests that there is little reason to believe that job seekers start with one type of strategy, say formal channels, and exhaust it before turning to a different type of strategy, say informal strategies. Second, regression analyses (not shown) reveal no significant correlation between the number of search strategies and weekly earnings, net of human capital, gender, and city of residence. Had there been a strong negative correlation, it would have supported the "maximizing" argument, since individuals using fewer strategies would presumably enter better paying jobs. Overall, these clues suggest that job seekers look for employment in a variety of ways simultaneously and accept reasonable offers that are among the first to come along. Further research into the range and sequencing of such offers by race and neighborhood context would add greatly to our current understanding of labor market processes and urban inequality.

Finally, we would be remiss if we did not acknowledge potential shortcomings associated with our aggregation of "Latinos" - a pan-ethnic category consisting of very different groups who do not necessarily share anything beyond a common language. While our side analyses (see footnotes) indicate that major findings summarized above hold for all three major Latino groups in our sample-Mexicans, Puerto Ricans, and Dominicans-further analysis is clearly needed to confirm this generalization. Dominicans, because they are often of African descent and thought to be "black" by many white employers, offer perhaps the most illuminating case for probing the extent to which employer discrimination mediates the possibility of densely connected, and highly localized job networks in poor inner-city neighborhoods. We look forward to future research in this area.

\section{References}

Alba, Richard D., John R. Logan, and Paul Bellair

1994 "Living with crime: The implications of racial/ethnic differences in suburban location." Social Forces 73:395-434.

Anderson, Elijah

1990 Streetwise: Race, Class, and Change in an Urban Community. Chicago, IL: University of Chicago Press.

Aponte, Robert

1996 "Urban employment and the mismatch dilemma: Accounting for the immigrant exception." Social Problems 43, 3:268-283.

Billy, John O. G., and David Moore

1992 "A multilevel analysis of marital and non-marital fertility in the United States." Social Forces 70:977-1011.

Brewster, Karin L., John O. G. Billy, and William R. Grady

1993 "Social context and adolescent behavior: The impact of community on the transition to sexual activity." Social Forces 71:713-740.

Briggs, Xavier de Souza

1998 "Brown kids in white suburbs: Housing mobility and the many faces of social capital." Housing Policy Debate 9, 1:177-221.

Brooks-Gunn, Jeanne, Greg J. Duncan, and J. Lawrence Aber, eds.

1997 Neighborhood Poverty: Policy Implications in Studying Neighborhoods. New York: Russell Sage.

Brooks-Gunn, Jeanne, Greg J. Duncan, Pamela Kato Klebanov, and Naomi Sealand

1993 "Do neighborhoods influence child and adolescent development?" American Journal of Sociology 99:353-395. 
Cohn, Samuel, and Mark Fossett

1996 "What spatial mismatch?: The proximity of blacks to employment in Boston and Houston." Social Forces 75, 2:557-572.

Crane, Jonathan

1991 "The epidemic theory of ghettos and neighborhood effects on dropping out and teenage childbearing." American Journal of Sociology 96:1226-1259.

Drennan, Matthew, Emmanuel Tobier, and Jonathan Lewis

1996 "The interruption of income convergence and income growth in large cities in the 1980s." Urban Studies 33:63-82.

Elliott, James R.

1999 "Social isolation and labor market insulation: Network and neighborhood effects on less-educated urban workers." The Sociological Quarterly 40, 2:199-216.

2000 "Class, race and job matching in urban labor markets." Social Science Quarterly 81, 4:1036-1052.

Entwisle, Doris R., Karl L. Alexander, and Linda Steffel Olson

1994 "The gender gap in math: Its possible origins in neighborhood effects." American Sociological Review 59:822-838.

Falcon, Luis M.

1995 "Social networks and employment for Latinos, blacks and whites." New England Journal of Public Policy 11:17-28.

Falcon, Luis M., and Edwin Melendez

1996 "The role of social networks in the labor market outcomes of Latinos, blacks and non-Hispanic whites." Paper presented at the Russell Sage Foundation Conference on "Residential Segregation, Social Capital and Labor Markets," New York, New York.

Freidenberg, Judith, ed.

1995 The Anthropology of Lower Income Urban Enclaves: The Case of East Harlem. New York: New York Academy of Sciences.

Granovetter, Mark S.

1974 Getting a Job: A Study of Contacts and Careers. Cambridge, MA: Harvard University Press.

1995 "Afterword 1994: Reconsiderations and a new agenda." In Getting a Job: A Study of Contacts and Careers, second edition, 139-1 82. Chicago, IL: University of Chicago Press.

Green, Gary P., Leann M. Tigges, and Daniel Diaz

1999 "Racial and ethnic differences in job search strategies in Atlanta, Boston and Los Angeles." Social Science Quarterly 80, 2:263-278.

Hagan, Jacqueline M.

1998 "Social networks, gender, and immigrant incorporation: Resources and constraints." American Sociological Review 63:55-67.

Hanson, Susan, and Geraldine Pratt

1995 Gender, Work, and Space. NY: Routledge.

Hogan, Dennis P., and Evelyn M. Kitagawa

1985 "The impact of social status, family structure, and neighborhood on the fertility of black adolescents." American Journal of Sociology 90:825-852.

Holzer, Harry J.

1987 "Informal job search and black youth unemployment." American Economic Review 77:446-452.

1988 "Search method use by unemployed youth." Journal of Labor Economics 6:1-20.

1996 What Employers Want. New York: Russell Sage Foundation.

Jargowsky, Paul A.

1997 Poverty and Place: Ghettos, Barrios, and the American City. New York: Russell Sage Foundation.

Johnson, James H. Jr., Melvin Oliver, and Lawrence Bobo

1994 "Unraveling the paradox of deepening urban inequality: Theoretical underpinnings and research design of a multi-city study." Urban Geography 15:77-89.

Kasinitz, Philip, and Jan Rosenberg

1996 "Missing the connection: Social isolation and employment on the Brooklyn Waterfront." Social Problems 43, 2:180-196.

Kirschenman, Joleen, and Kathryn Neckerman

1991 "We'd love to hire them but. . . . The meaning of race to employers." In The Urban Underclass, Christopher Jencks and Paul E. Peterson, eds., 203-232. Washington, DC: Brookings Institution.

Liebow, Eliot

1967 Tally's Corner: A Study of Negro Streetcorner Men. New York: Little, Brown. 
Light, Ivan, and Stephen Gold

2000 Ethnic Economies. San Diego: Academic.

Logan, John R., Alba, Richard D., and McNulty, Thomas L.

1994 "Ethnic economies in metropolitan regions: Miami and beyond." Social Forces 72:691-724.

Marx, Jonathan, and Kevin T. Leicht

1992 "Formality of recruitment to 229 jobs: Variations by race, sex, and job characteristics." Social Science Research 76:190-196.

Massey, Douglas S.

1998 "Back to the future: The rediscovery of neighborhood context." Contemporary Sociology 27, 6:570-572.

Massey, Douglas S., and Nancy Denton

1993 American Apartheid: Segregation and the Making of the Underclass. Cambridge, MA: Harvard University Press.

Massey, Douglas S., Rafael Alcaron, Jorge Durand, and Humberto Gonzalez

1987 Return to Aztalan: The Social Process of Migration from Western Mexico. Berkeley: University of California Press.

Massey, Douglas S., Andrew B. Gross, and Kumiko Shibuya

1994 "Migration, segregation, and the geographic concentration of poverty." American Sociological Review 59, 3:425-445.

Mier, Robert, and Robert Giloth

1985 "Hispanic employment opportunities: A case of internal labor markets and weak-tied social networks." Social Science Quarterly 66:296-309.

Miethe, Terance D., and David McDowall

1993 "Contextual effects in models of criminal victimization." Social Forces 71:741-759.

Model, Suzanne

1993 "The ethnic niche and the structure of opportunity: Immigrants and minorities in New York City." In The Underclass Debate: Views from History, Michael Katz, ed., 161-193. Princeton: Princeton University Press.

1997 "Ethnic economy and industry in mid-twentieth century Gotham." Social Problems 44:445463.

Montgomery, James D.

1992 "Job search and network composition: Implications of the strength of weak ties hypothesis." American Sociological Review 57:586-596.

Moss, Philip, and Chris Tilly

1996 "'Soft' skills and race: An investigation of black men's employment problems." Work and Occupations 23, 3:252-276.

Portes, Alejandro, and Robert Bach

1985 Latin Journey: Cuban and Mexican Immigrants in the United States. Berkeley, CA: University of California Press.

Rosenbaum, James E., and Susan J. Popkin

1991 "Employment and earnings of low-income blacks who move to middle-class suburbs." In The Urban Underclass, Christopher Jencks and Paul E. Peterson, eds., 342-356. Washington, DC: Brookings Institution.

Smith, Douglas A., and G. Roger Jarjoura

1989 "Household characteristics, neighborhood composition, and victimization risk." Social Forces 68:621-640.

Waldinger, Roger

1996 Still the Promised City?: African-Americans and New Immigrants in Postindustrial New York. Cambridge, MA: Harvard.

1997 "Black/immigrant competition re-assessed: new evidence from Los Angeles." Sociological Perspectives 40, 3:365-386.

Wilson, William Julius

1987 The Truly Disadvantaged:The Inner City, the Underclass, and Public Policy. Chicago, IL: Chicago University Press.

1996 When Work Disappears: The World of the New Urban Poor. New York: Alfred Knopf.

Winship, Christopher, and Larry Radbill

1994 "Sampling weights and regression analysis." Sociological Methods and Research 23:230-257. 